REVIEW ARTICLE

\title{
POLITICAL IMPLICATIONS OF LAW IN THE FORMATION OF LAW NO. 13 OF 2003 CONCERNING WORKERS PROTECTION IN EMPLOYMENT AGREEMENT SPECIFIC TIME (EAST/PWKT)
}

\author{
Muhammad Bram Glasmacher \\ Pusat Pengelolaan Komplek Gelora Bung Karno (PPKGBK) \\ $\triangle$ bramglasmacher@gmail.com
}

\section{CITED AS}

Glasmacher, M.B. (2020). Political Implications of Law in the Formation of Law No. 13 of 2003 concerning Workers Protection in Employment Agreement Specific Time (EAST/PWKT). Journal of Law and Legal Reform, 1(3), 517-530. DOI: https://doi.org/10.15294/jllr.vli3.36702

\begin{abstract}
Basically social protection is a labor protection which aims to ensure that workers / laborers are valued for their dignity and status as human beings, not only as a factor of production (external factors, but are treated as humans with all their dignity and values (internal or constitutive factors). Law in the Formation of Law No. 13 of 2003. This research study uses a research method with a normative juridical approach with data collection techniques in the form of library research. Political Politics in Lawmaking No. 13 of 2003 is influenced by the spirit of reform to better provide protection for workers / workers after the "dark era" in the new order, and because of the problems of era labor, it has to do with the economic problems in a country, especially in Indonesia, which is a developing country, which in the process of making this law is closely linked to economic politics clear from the implications for PKWT workers. Where this is still a pros and cons. However, this is like a double-edged knife. In terms of politics clearly this can reduce unemployment but also the number of Workers / Workers who do not understand the protection they should get. Weak understanding of the public, especially employees in private companies of labor regulations, is very likely to create injustices and legal violations that are legalized and last for a long period of time or may even last forever, even though in terms of the Manpower Act, sanctions are imposed on companies and / or individuals who violate the Law are severely punished.
\end{abstract}

Keywords: Political Law; Labor Law; Labor Protection; PKWT; EAST 


\section{TABLE OF CONTENTS}

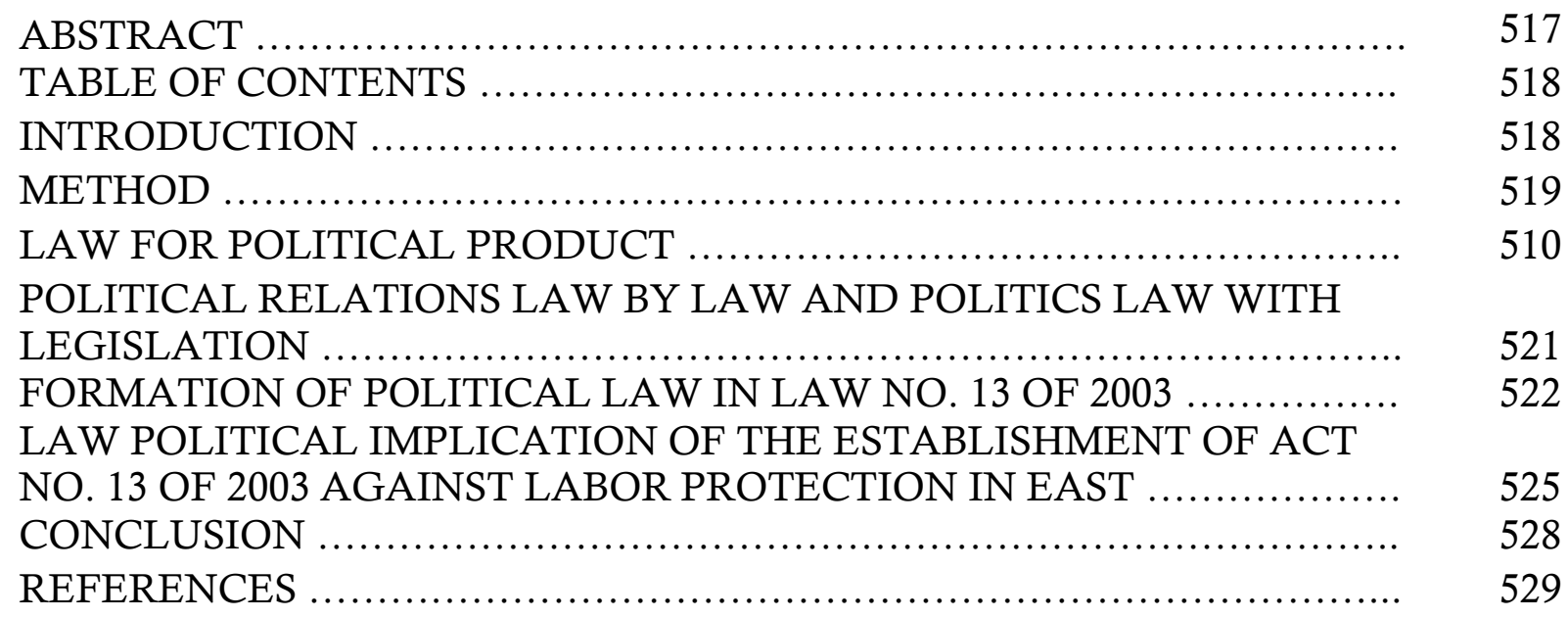

\section{INTRODUCTION}

Act 13 of 2003 on Manpower issued at the time of President Megawati. Where legally in Article 5 of the Act provides protection that all workers are entitled to and have the same opportunity to get a job and a decent living regardless of gender, ethnicity, race, religion and political orientation in accordance with the interests and abilities of labor concerned, including equal treatment of persons with disabilities (Khakim 2003).

Labor protection itself can be classified into three kinds, namely Protection economically, namely the protection of workers in the form of an adequate income, including when labor does not work outside of will, social protection, namely the protection of labor in the form of health insurance work, and the right to organize and the right to organize, and the protection of technical, such as labor protection in the form of security and safety (Asikin 2002).

Related Legal Politics in the formation of this legislation, it is interesting to discuss because over two hundred (200) years, the legislature is a key institution in the political development of modern countries (Biynton \& Kim on Isra 2010). Political law can be divided into two dimensions. The first is the political dimension of law as the basic reason of the holding of a legislation. The second dimension is the purpose or reason that appears behind the enactment of a legislation (Rajaguguk 2004).

In view of Machiavelli that eliminates the distance between law and force states that the law is nothing but a tool of legitimacy of power and can be a justification of violence (Baswir 1993). The position of labor by employers that are not balanced, the 
necessary role of the State to protect workers as the weaker party, which by law/legislation particularly the Manpower Act in order to achieve a balance which bring society the purpose of the State which guarantee a decent life for humanity of each citizen (Zaeni 2007). To set this, the government issued Law No. 13 Year 2003 on Manpower. In the Act is one of them regulates the Employment Agreement Specific Time (EAST).

Employment Agreement setting specific time periods in Law No. 13 of 2003 on Labor regulated in Article 56 to Article 59, which can be generally stated that the Employment Agreement Specific Time For no trial period, only apply to the job type and nature completed within the specified time, the job of all kind of selection or temporary or work related to the product or a new activity or product in the experiment.

In addition, the set also that the Employment Agreement for specific time periods are not allowed to work that is permanent, work contracts for a certain period of time is based on a certain time period can be held for a maximum of two (2) years and may only be extended for 1 (one) for a period a maximum of 1 (one) year. If employers want to extend the Employment Agreement Specific Time (EAST) that certain, at least seven (7) days before the Employment Agreement Specific Time (EAST) ends has notified the intention in writing to the worker / laborer. Employment agreement that does not meet these conditions should be changed to Time Indefinite Employment Agreement or in other words, the workers appointed as permanent employees (Uwiyono 2003).

Social protection is primarily a labor protection aimed at keeping workers / laborers appreciated the worth and dignity as human beings and not just as a production factor (external factor, but rather treated as human beings with dignity and values (internal or constitutive factor) (Uwiyono 2003).

\section{METHOD}

This research study uses juridical normative research method. The approach in this study include law approach and concept approach to be used continuously and interrelated, in order to obtain further data can be reviewed, analyzed and interpreted. With the approach used is expected to explain the problems in the study of the dynamics arising from the rules regarding Law Political Implications of the Establishment of Act No. 13 in 2003 Labor Protection Against In EAST. 


\section{LAW FOR POLITICAL PRODUCT}

Moh. Mahfud MD found that legal politics is "Legal Policy" of the laws that apply or not apply weeks to achieve the objectives of the State. In this case the law is positioned as a tool to achieve the purpose of the State. Related to this Suyaryati breathing Hartono argued about the "law as a tool" in practice, politics is also legal political law as the means and rare that governments can use to create system national law in order to achieve the ideals of the nation and the destination country (Mahfud MD 2011).

The basic assumption used of this study is law is a political product that content of the character of each product will be very defined or characterized by the political balance of forces or a par which gave it birth. Assumption has been based on the fact that any legal product is a product of political decisions so that the law can seen as a crystallization of the political thought of interacting among politicians. Although in terms of "das sollen" there is a view that politics must be subject to the provisions of the law, but these studies more viewing angle "das sein "or empirical that law that were in fact determined by political configuration as its background. Instrumental function law as a tool of political power noticeably is more dominant than the other functions. Moreover, a phenomenon that can be seen from the growth of legal institutions, values and procedures, legislation and law enforcement bureaucracy not only reflects the law as a condition and development process but also a strong supporting structure of the political, economic, social (Mahfud MD 2011).

Law was given primary function as an instrument development program because the law is not really the main goal. Thus, it can be understood if there is tendency that law adopted in order to facilitate and political support. As a result, all the rules and laws that are considered not to create political stability and economic growth must be changed or abolished. Thus, as a political product, the law can be used as a means of justification for the political vision of entrepreneurs. In fact, activity legislative (legislation) is more political decisions load imbalance run those jobs so meaningful legislative institutions closer to politics than law (Mahfud MD 2011).

Theoretically legal relationship with politics can indeed be distinguished on three different relationships. First as das sollen, accepted the law on political as any political agenda should be subject to the rules of the rules. Both das sein, political determinant of the law because the law is in fact a political product of any legal, therefore, in front of us the other is the crystallization of competing political will. 
Third, the political and legal related inter-determinant political justice and without be unjust law while the law without political guard will be paralyzed. Law in this context is defined as law-pelicang created by the agency legislative (Mahfud MD 2010).

\section{POLITICAL RELATIONS LAW BY LAW AND POLITICS LAW WITH LEGISLATION}

Some of the literature reveals that the law is regarded as the goal of politics. Politics is the intent of the law so that ideas or rechtsidee such as freedom, fairness, predictability, and so placed in the positive law and the implementation of part or the whole, of the idea of law that is the goal of the political process. Second, that the law as well as a tool of politics. In this case the political use of positive law (legislation) to achieve its objectives in terms of the realization of the ideas of the law.

Accordingly, the existing regulations or society to a certain destination. In this regard, we recall the term that the law is a social engineering tool or a tool of social engineering. politics and law have the same roles and tasks that solve social problems in which politics is dynamic and legal aspects of the static aspect.

From what has been described, it becomes clear that the relationship between politics and the law is the basis of political law provided that the implementation of the legal political development can not be separated with the implementation of the overall political development. Alternatively, it can be said, the basic principles are used as political development provisions will also apply to the implementation of legal politics realized through legislation.

Legislation is part of our laws made deliberately by the state institutions. It did not appear suddenly. However, it made with a purpose and a reason. Considering there should be consistency and correlation between what is defined as a legal political with a goal to be achieved. law politics can be divided in two dimensions. The first is the political dimension of law as the basic reason of the holding of a regulation legislation. law politics with the basic reasons such dimensions according to Hikmahanto as "basic policy" or in English is called "basic policy".

The second dimension of the politics of law is the purpose or reason that appears behind the enforcement of a regulation legislation, which is then referred to as the "Policy Entry" or in English as "enactment" policy. Through "enforcement policy" to do the identification of these various policies the enactment of legislation in Indonesia 


\section{FORMATION OF POLITICAL LAW IN LAW NO. 13 OF 2003}

The Constitution of Republic Indonesia 1945 ensured that every citizen is entitled to work and a decent living for humanity (Art 27(2)). Also the objective of the State Government in 1945 opening paragraph IV, among which is to promote the general welfare. Designed to promote the general welfare of social justice according to the 1945 opening proves that the Indonesian state since its inception as a welfare state (Sihombing 2008; Putri \& Arifin 2019).

The formation process so that the Labor Law actually watched the Legal Protection against Labor because the real Whatever is done within the law, we should never ignore the human aspect as the central part of the law, because the law was made for man, not vice versa. Therefore, in any proceedings in a State of law, human aspects must occupy a central position, including allowing people to participate in a process that determines the fate. Only then, the ideals to make the State under the law as the home of the people of Indonesia are orderly and convenient reality (Rahardjo 2003). However Indeed, it is known that the form of government attention often by issuing a legal product, but often the role of interest groups in the formation of law is dominant, so the law as not separated of other social subsystems included in the product (Mahfud MD 2006).

Law as translated through the materialization of their text has been placed as the political configuration that works. That is, the law has been made aware by the maker / taker wisdom with some understanding and interest they have. Therefore, although the law is believed to have values and meanings are very important in managing social life, he remained as a result of friction and attraction of political representation-specific economic power in influencing it (Perdana 2006; Arifin 2019).

In other words, the laws that are in power become increasingly helpless state when practices of politicizing more dominant than the actual practice of law. Enforcement is losing space, related to such issues Ronald Katz stated that what happened in Indonesia is a law without law, no law but useless (al-Akhlaq 2011).

Labor is a group of workers in a business field is an important partner for entrepreneurs in the wheels of economic activity. On one hand, entrepreneurs have the capital and require workers to carry out certain tasks for the benefit of employers, and on the other hand the workers need jobs and contribute energy and mind to carry out the work assigned to him by the businessman received a number of rewards determined. But often violations of labor rights committed by the employer, which is 
for example violations of wage payments under government regulatory standards or the payment of overtime under the terms of the government and others (Mahasin, Naziah, \& Arifin 2020).

Renewal of government regulations on employment from time to time is a manifestation of the government's commitment to continuously improving the normative rules of employment to meet the world's sense of justice for employment in which there are employers and workers. Labor provisions issued by the government aims to regulate the life of labor in Indonesia, but the government also often issued wisdom normative rules are not clear and do not set out detailed rules were causing a lot of meaning interpretation by the employer, it would be much conflict between employers and workers.

Act No. 13 of 2003, Article l (14) on Labor to give understanding labor agreement is an agreement between the workers and employers or employer which contains the terms of employment rights and obligations of both parties. But in a labor agreement is not a purely civil. Because Indonesia based on Law No. 13 of 2003 embraced the Industrial Relations System, in which these relationships are related parties, namely the employees / workers, employers and the Government. Where They arise due to participate in the government in addressing employment problems through legislation, with the aim of creating and realizing fair working relationship (Art 1 (16)).

When we look back on how the politics of labor law after the independence of Indonesia in the era of the old order, or at least until 1965, is the position of the workers is only for the exploitation of physical needs alone, which is only employed at the plant for the benefit of the production process and never noticed right labor essential for the provision of welfare cover; wage issues which deserve to be given the employer to the worker (Arifin \& Arifin 2019; Arifin 2020; Mahasin, Naziah, \& Arifin 2020).

In the era of the old order, the role of the workers is very important to the engagement of maintaining national independence by creating a movement "Labor Unions, Workers and Trade Unions in Indonesia" were active in defending the independence of Indonesia to escape from Dutch colonial rule, the Japanese, and the Allies who wanted recapturing that the shape of the workers intervened in policy formation and labor law in Indonesia after independence government in 1945. Then, the contribution of the success of the labor movement to defend the independence of Indonesia put position of the workers are in a strategic position.

With the intervention of the workers in the establishment of policies and labor law in the government, then the rule is formed tends to advance and protect the 
workers, including; Act no. 1 in 1951 Applicability Statement Law 12 in 1948 on Labor Protection, Law No. 2 in 1951 Enactment of Law No. 33 in 1947 concerning Safety in the Workplace, Law No. 3 in 1951 regarding the Applicability Statement Law 23 in 1948 on Labor Inspection, Law No. 21 in 1954 About the Labor Agreement between the Trade Unions and Employers, Act No. 18 in 1956 which ratified ILO Convention No. 98 About the Right to Organize, Act No. 22 in 1957 about the Settlement of Labor Disputes, law No. 3 in 1958 About the Employment of Foreign Nationals (Tedjasukmana on Sinaga 2006).

In the New Order of Suharto Policy, ruling political control of labor is primarily intended to eliminate the influence of the Left flow of the labor movement in the political arena at large. In addition, the main feature of worker-employer accommodation-state during the new order is a very strong state control over labor organizations and persistent denial of the working class as a social force. In terms of labor policies carried out in this period is strongly influenced by an economic stability to stop the economic downturn after the incident G30S/PKI. It is indeed evident from the program Repelita by the new order (Agusmidah 2010).

Entering the reform era in 1998, with the spirit of reform policies issued by the government in the reform era in economic matters also directed to follow the policy flexibility of labor relations and investment climate that has worldwide in accordance with the development of globalization, liberalization and free market. Since the core of the flexibility of the employment relationship is the freedom to mobilize and implement a system of labor relations in accordance with the needs of a flexible labor market (Agusmidah 2015). So, of economic policy made by the government in the reform era either directly related to employment issues and policies relating to investment, it is clear that flexibility policies geared working relationship (Agusmidah 2015).

Then, in the era of the so-called post-reform, some of the demands put forward the community will remain, especially related to the sector - a sector that has not been achieved in the reform period. Sector - the sector which are related to the rule of law, human rights, and the eradication of corruption, collusion and nepotism. Besides, it also will always appear on the fulfillment of the demands of justice in the economic field (Arinanto 2006).

When discussing the economy, it can be separated from the Chinese State. Chinese as Asian tiger that became one of the strongest countries in the world's economy has done a total legal reform, creating a law based on the economy so that the law could facilitate economic and answered all the existing economic problems. Where the country since the beginning of the 1980s, beginning of the rapid 
development vesting legislative power cannot be avoided. Legal mechanisms essential for a modern country to strengthen the administration of this system vesting legislative power also promotes the development of the country, a reflection of the positive consequences of the rebuilding of China's legal system and economic restructuring (Xichuan \& Lingyuan on Arinanto 2001).

This needs to be discussed as well as the economy is closely related to labor issues as described above, that Labor is a group of workers in a business field is an important partner for entrepreneurs in the wheels of economic activity. Because labor issues are based on the spirit of reform when the monetary crisis in 1997, it shows how vulnerable the nation's economy was built during this time that demands for reform which economic disruption brought great suffering to many residents and contribute to regular outbreaks of social conflict, including ethnic and religious clashes in various parts of the country. So, the emergence of Termination of Employment where even though many of them, especially the worker's status as employee EAST.

The relationship between the legal protection of workers / labors in employment agreement specific time (EAST) with economics because EAST is part of legal changes in the field of employment/labor. Where is Indonesia after the reform and will undergo an industrialization phase (Art. 56 (2)). In the industrialization phase characterized by the accumulation of capital and economic growth, where the law in favor of the industrialists, the rules EAST born to answer the needs of industrialization (Art. 56 (2)).

\section{LAW POLITICAL IMPLICATION OF THE ESTABLISHMENT OF ACT NO. 13 OF 2003 AGAINST LABOR PROTECTION IN EAST}

Employment Agreement according to the law No. 13 in 2003, is divided into two, namely the Employment Agreement Specific Time (EAST) and Employment Agreement Unspecific Time (EAUT). Where Employment agreements are made for a certain time (EAST) must be in writing. This provision is intended to better ensure or maintain things that are not desirable in connection with the termination of employment contract. EAST shall not require the presence of probation.

EAST actually are still raise the pros and cons. Where in the formation of this Act in fact the legislators argued to reduce unemployment. When compared with Act earlier, on Law No. 12 of 1948 and Act No. 14 of 1969, the employment relationship is not fixed. There is no organized, the reverse is also no prohibited, so use it as a habit. 
While in Law Number 13 in 2003 on Manpower provides a stronger legal basis than the previous law. EAST where there are separate settings in sub-chapter on employment. Then made the norm of the executive, namely the Ministry of Manpower and Transmigration No. KEP.100 / MEN / VI / 2004.

After the reform and the release of this Act shall in this period noticed among others the interests of labor then the demands on government intervention through the establishment of laws that protect the weaker is very strong. Especially these EAST problems as described above raises the pros and cons.

The number of practices that deviate from the provisions of this law is one of the demands of the workers at the time of massive demonstrations. Because it is in the process of its formation as described above to accelerate the process of economic growth but forget about workers' rights.

Because basically the system of relations workers with employers a nation always reflects a development system that is basically a reflection of the economic system or the system development and ideology embraced. For example, the economic system which is too liberal, capitalist or etatist paced, communistic will bear the same system of industrial relations as its reflection.

So in the end the economic political influence is also crucial Employment Law, because basically these two things cannot be separated in the era of globalization of trade, the applicable law is the law of the free market that requires the government's role be on the wane and even become larger private role. This law applies also to the field of employment (Uwiyono 2003).

However, not all things in Employment Law can be submitted on market mechanisms. In addition, the law system of Indonesia also did not give room spacious enough for it. This was where the government was challenged to run a labor policy that is able to accommodate all the interests, both owners of capital, workers / laborers and the government itself.

Not to mention if it is the Indonesian people better understand values of justice in the community so there are many people who still customary law uses resolve any legal issues rather than find out about the national law itself (Lubis in Arinanto 2016). No exception to the workers who were low educational level does not understand the national laws actually protect them in EAST issue. So that there are problems here and there in the process of this legal protection.

It can also be caused when viewed sociologically worker is the person or group that is not free, which means it is a person who has no life provision other than strength alone, he was forced to work on other people and employers this is basically 
determine the terms of employment that (Finawati 2003). Because that Indonesia is a developing country where jobs are not balanced with the available labor.

Real law has become a tool of social change. Legally required to take actions that affect people, property or the rights of everybody. Requests for legal practitioners was never satisfied until today (Jain 1989). This also applies in the Law of Political implications of this Act to Workers EAST that this legislation should be a tool to influence the employers to pay more attention to the provisions of the workers / laborers EAST.

Koffi Anan himself argued that the economic rights and social responsibility are two sides of the same coin. That is why a few years ago in Davos, he proposed a global equation between the PBB business. He also asked them to take action within their sphere of influence (PBB), in accordance with internationally accepted standards in the field of human rights, labor standards, and environmental-United Nations system and offer services to help them do so (Annan 2000).

Then Government intervention to enforce the rules of Labor is also indispensable in Pancasila Industrial Relations system. Besides efforts to resolve business disputes including labor issue should be able to give justice without inhibiting economic growth. Where is fronted bipartite and tripartite in labor disputes. For as by Friedman, in the end, if the courts cannot solve the problem and if the problem does not disappear by itself (through a radical change in popular tastes or tolerance level), some solutions outside the law will be achieved (Friedman 1967).

Protection of workers/labors who use Employment Agreement Specific Time (EAST/PWKT) as stipulated in Law No. 13 of 2003 on Labor and its implementing regulations, namely in Article 59 paragraph (1) of Law Number 13 of 2003 on Labor which states that the work agreement for a specified time can only be made for specific jobs by type and nature of the job will be completed within a certain time, namely:

a. Jobs that once completed or are temporary in nature,

b. Work completion is expected not too long and not later than 3 (three) years, and

c. The work is seasonal; or works related to new products, new activities, or additional products that are still in experimental or exploratory.

Also, in Article 88 paragraph (1) and (2) of Law Number 13 of 2003 on Labor states that each worker / labor is entitled to the income that meets a decent living for humanity. And to realize earnings that meet a decent livelihood for humanity, the government set a wage policy that protects workers / labors. 
The purpose of government intervention in the labor area is to realize a fair labor, because the legislation of labor gives rights for laborers / workers as a whole human being, because it must be protected both with regard to their safety, health, decent wages and so on. Also, the government must also consider the interests of employers / employer the continuity of the company (Husni 2011).

Supervising the implementation of the legal provisions (law enforcement) in the field of labor / employment will ensure the implementation of the basic rights of workers, which in turn have an impact on its stability. Besides labor inspection will also be able to educate employers and workers to always obey the provisions of the legislation in force in the field of employment so that disputes occurred because employers do not provide legal protection to workers in accordance with applicable regulations.

The government (state) must be able to position itself as a wise regulator by means of the establishment and implementation of the Employment Law Employment Law due will be the primary means to carry out government policy in the field of labor itself. Employment policies (labor policy), in Indonesia can be seen in the 1945 Constitution as the Constitution of the State, also in the legislation concerned.

Especially with regard to employment, if observed, the 1945 Constitution actually contains the politics of law on employment, which is in Article 27 of the 1945 Constitution and Article 28D, of these two chapters can be withdrawn their legal politics in the field of employment, which is to create rules that protect the right of every person to work and protect every person in his job.

At the end of the formation of these labor laws of the previously described because it is their political importance in the economy is inseparable from testing this law against the Constitution. Where in the first one made by Judge John Marshall as US Supreme Court Justice in the case of Marbury v Madison-known by the term Judiciary Act (1789) because the substance is contrary to the constitution (Rehnquist 1989). One such case is the Constitutional Court Decision No. 7 / PUU-XII / 2014 concerning the shift worker status EAST be EAUT So that future needs to be considered by the authors do Judicial Review by Parliament with more advanced aspects of Labor Protection rather than political.

\section{CONCLUSION}

Political Law in the Making of Act No. 13 of 2003 influenced the spirit of reform to give greater protection to the labors / workers after the "dark era" in the new order. Moreover, because the labor issues related to a country's economic problems, 
especially in the State of Indonesia which is a developing country. Where in the process of enactment of this Act closely with economic policy. It is apparent from the implications for workers EAST. Where it is still the pros and cons. However, it's like a double-edged knife. In political terms this clearly can reduce unemployment but also many Labor / Workers who do not know with the protection they are supposed to get, so that the need of judicial review of this legislation so that more priority is the legal protection of workers as citizens rather than more advanced aspects of the legal political and economic policy to make it easier for entrepreneurs and investors in the hiring of workers in EAST. So that it is also necessary to create a government oversight of industrial relations its aspired Pancasila.

\section{REFERENCES}

Arifin, R. (2019). Indonesian Political Economic Policy and Economic Rights: An Analysis of Human Rights in the International Economic Law. Journal of Private and Commercial Law 3(1), 38-49. DOI: 10.15294/jpcl.v3il.18178.

Arifin, W., \& Arifin, R. (2019). Asas Keadilan Upah Guru Honorer dalam Perspektif Hukum (Principle of Justice for Honorary Teacher Wages in a Legal Perspective)'. Riau Law Journal 3(1), 85-104.

Arifin, R. (2020). Legal Services and Advocacy in the Industrial Revolution 4.0: Challenges and Problems in Indonesia. Indonesian Journal of Advocacy and Legal Services, 1(2), 159-162. https://doi.org/10.15294/ijals.vli2.36488.

Arinanto, S. (2001). Politik Hukum 2. Jakarta: Program Pasca Sarjana FH UI.

Arinanto, S. (2001). Politik Hukum 3. Jakarta: Program Pasca Sarjana FH UI.

Asshiddiqie, J. (2002). Konsilidasi Naskah UUD 1945 Setelah Perubahan Keempat. Jakarta: PSHTN FHUI.

Chanddrawulan, A.A. (2011). Hukum Perusahaan Multinasional, Liberalisasi Hukum Perdagangan Internasional dan Hukum Penanaman Modal. Bandung: PT. Alumni.

Erawaty, E. (2015). Legal Aspects of Foreign Direct Investment in Indonesia: An Overview. Jakarta: ThaiFTA.

Friedmann, L.M. (1990). Teori dan Filsafat Hukum. Jakarta: Rajawali Press.

Graham, E.M., \& Krugman, P. (1995). Foreign Direct Investment in The United States. Washington: Institute for International Economics. 
Hartono, S. (1982). Hukum Ekonomi Pembangunan Indonesia. Bandung: Binacipta.

Hampton, M.R., \& Abbott, J.P. (1999). Offshore Finance Centres and Tax Havens: The Rise of Global Capital. London: Mac Millan.

Hatta, M. (1977). Menuju Negara Hukum. Jakarta: Idayu Press.

Komar, M. (1999). Kumpulan Karya Tulis Menghormati 70 Tahun Prof. DR. Mochtar Kusumaatmadja, SH, LLM. Bandung: Alumni.

Lev, D.S. (1990). Hukum dan Politik di Indonesia: Kesinambungan dan Perubahan. Jakarta: LP3ES.

Mahasin, Z. Z., Naziah, F., \& Arifin, R. (2020). Wage Problems in Indonesia in the Human Rights Perspective (Case of Inappropriate Wages for Pot Workers in Tangerang). The Indonesian Journal of International Clinical Legal Education, 2(1), 1-14. https://doi.org/10.15294/ijicle.v2il.37326.

Mahfud MD, M. (2006). Politik Hukum di Indonesia. Jakarta: Rajawali Press.

Marbu, S.F. (2011). Peradilan Administrasi Negara dan Upaya Adninistratif di Indonesia. Yogyakarta: FH UII Press.

Mertokusumo, S. (2001). Penemuan Hukum Suatu Pengantar. Yogyakarta: Liberty.

Nasution, A. (2009). Penerapan Prinsip Transparansi dalam Undang-Undang Nomor 25 Tahun 2007 Tentang Penanaman Modal Kaitannya dengan Domestic Regulation WTO. Thesis, Univesitas Sumatera Utara.

Putri, A.R.H., \& Arifin, R. (2019). 'Perlindungan Hukum Bagi Korban Tindak Pidana Perdagangan Orang di Indonesia (Legal Protection for Victims of Human Trafficking Crimes in Indonesia)'. Res Judicata 2 (1), 170-185. DOI: http://dx.doi.org/10.29406/rj.v2il.1340.

Rais, M.A. (2008). Agenda Mendesak Bangsa: Selamatkan Indonesia! Yogyakarta: PPSK Press.

Sihombing, J. (2008). Investasi Asing Melalui Surat Utang Negara di Pasar Modal. Bandung: PT. Alumni. 